\title{
Um partido em dois tempos: o Partido Comunista Brasileiro (PCB) nas conjunturas pré e pós golpe de 1964
}

\section{A party in two stages: the Brazilian Communist Party (PCB) before and after coup d'etat of 1964}

\author{
Marco Aurélio Santana \\ Universidade Federal do Rio de Janeiro \\ msantana@ifcs.ufrj.br
}

(Brasil)

Recibido: $18-05-2019$

Aceptado: 20-11-2019

Publicado: 05-06-2020

\section{Resumo}

O objetivo do presente artigo é analisar, a partir de pontos específicos, a atuação do Partido Comunista Brasileiro (PCB) e sua militância em duas conjunturas distintas. Uma, marcando o ascenso da trajetória desse partido, que vai de 1945 até 1964, se encerrando no golpe de Estado de 1964. E outra, marcando a descenso de suas ações, que vai de 1978 até 1992 . Tendo em vista sua força concreta, a relação do partido com o movimento dos trabalhadores brasileiros será o eixo condutor central de análise.

Palavras-chave: $\mathrm{PCB}$, comunistas, sindicalismo, redemocratização, trabalhadores 


\begin{abstract}
The aim of this article is to analyze the actions of the Brazilian Communist Party (PCB) in two different periods. The first one, going from 1945 s redemocratization to the 1964 s coup d'etat, when we can witness an increase of Party's strength. The second one, going from 1978 to 1992, when the Party experienced a decreasing political influence. It will be done by taking into account the relationship between the Party and the labor movement as the focus of analysis.
\end{abstract}

Keywords: PCB, communists, trade unionism, democratization, workers

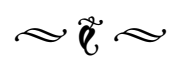

\section{Introdução}

O Partido Comunista Brasileiro (de agora em diante, $\mathrm{PCB}$ ) teve um lugar de destaque na história política brasileira. Quando terminou suas atividades em 1992, a organização havia se tornado o mais antigo e controvertido partido político nacional. Da fundação à autodissolução, oitenta anos depois, o PCB havia participado dos grandes momentos políticos do nosso século. ${ }^{1}$ Neste sentido, podemos dizer que, em certa perspectiva, o PCB exemplifica de forma cabal a articulação entre a história de um partido e a história da sociedade na qual se insere e atua. ${ }^{2}$ Falar da história do $\mathrm{PCB}$, portanto, é falar da história do Brasil de um ponto de vista específico, destacando um de seus aspectos característicos.

Se, já desde sua fundação, o PCB buscou intervir na realidade circundante, é a partir da

1. Note-se que, após um conjunto de disputas e polêmicas, um grupo retoma a trajetória de organização e ação do Partido. Ele volta à existência mantendo sua atuação no conjunto da esquerda brasileira até os dias de hoje.

2. Conforme indicado por Gramsci (1978).

174 conjuntura do após guerra que o partido dará um salto importante tanto em termos de sua inserção no sistema político quanto de sua expansão no movimento sindical. Este salto se desenvolverá ao longo da década de 1950, chegando mesmo ao seu ápice no início dos anos 1960, quando o trabalho anterior ruiu frente ao golpe militar de 1964. Em nenhuma outra conjuntura posterior a este evento, o partido alcançará a importância que obtivera antes do mesmo.

Com a instauração do regime militar em 1964, a crise vai atingir exatamente os dois flancos de atuação central do partido, os quais a organização buscava articular no sentido de participar do processo decisório na política nacional. No sistema político, a mão de ferro que se abateu não só sobre os militantes do $\mathrm{PCB}$, mas das esquerdas em geral, restringiu as possibilidades destes para o trânsito, formal ou informal, da ação político-partidária. No que diz respeito à sua atuação sindical, se a persistência do partido como referência à esquerda naquele movimento conseguiu sobreviver através de um trabalho de resistência dentro das fábricas e contínua atuação por 
dentro da estrutura sindical nos anos 19601970, ela não conseguiu fazer frente a nova realidade, em termos político-sociais, que despontará em fins dos anos setenta trazendo "novos" atores à cena.

A ideia do presente capítulo é analisar, a partir de pontos específicos, a atuação do PCB e sua militância em duas conjunturas distintas. Uma que vai de 1945 até 1964, se encerrando no golpe de Estado de 1964. E outra que vai de 1978 até 1992 . Tendo em vista sua força concreta, a relação do partido com o movimento dos trabalhadores será o eixo condutor central.

Uma análise como a que procedemos do que seria o apogeu e a crise de um partido situado à esquerda do espectro político e que, durante um longo período, foi uma referência importante enquanto representação dos interesses dos trabalhadores, em tudo o que este processo tem de específico e, ao mesmo tempo, no que traz de possibilidades generalizantes, pode auxiliar na ampliação do entendimento da prática de partidos com este corte em nosso país, bem como sobre as dificuldades que os mesmos encontram no desenvolvimento e implantação de suas propostas políticas.

\section{Os comunistas e as disputas no sindicalismo}

A história do PCB foi marcada por perseguição e banimento, o que, obviamente, obstaram muito suas ações, o partido procurou desenvolver um rápido caminho de ocupação de espaços no movimento sindical que lhe servissem como instrumentos para contrabalançar sua condição de partido ilegal e o credenciar enquanto força ativa no interior do cenário político nacional. $\mathrm{O}$ partido, da forma como pode, tentou articular as duas inserções. A organização fazia de seus vínculos com a classe operária e seu presumido ou efetivo controle sobre os sindicatos um elemento importante de sua tentativa de: primeiro, se manter no sistema político- tendo em vista as inúmeras pressões para o seu banimento -; depois, quando efetivada a sua ilegalidade, voltar por um caminho alternativo para dentro do sistema. ${ }^{3}$ Para um partido que na maior parte do tempo apostou na importância da atuação legal e da abertura de espaços democráticos, e que era mantido sob uma ilegalidade espúria, voltar ao sistema político com participação legal e aberta passou a ser quase uma obsessão. ${ }^{4}$

Tendo isso em vista, visando a partir de fora se credenciar para a entrada nas grandes disputas pelos destinos do país, independente da conjuntura, o partido acabou por tentar instrumentalizar sua relação com o movimento dos trabalhadores nesta direção. Desta forma é, que na maioria das vezes, a organização priorizava sua lógica de ação geral, mirada para a perspectiva institucional, em detrimento daquelas que seriam as demandas imediatas vindas da classe que dizia representar.

3. Como bem indicou Spindel (1980).

4. Um exemplo foi o ocorrido com a alteração do nome do partido sem que o congresso da entidade fosse ouvido, em uma conferência nacional no início dos anos sessenta, que mudou seu nome de Partido Comunista do Brasil para Partido Comunista Brasileiro. O presidente João Goulart jogou com esta disposição dos comunistas e indicava a possibilidade de conseguir-lhes a legalidade em troca de apoio. Em uma conjuntura posterior, fins dos anos setenta, o partido será acusado por setores mais à esquerda de assumir uma posição dócil e negocista com relação ao regime militar devido à esperança e crédito na conquista de sua legalidade. 
Dessa maneira, quase ignorando tais demandas que o PCB ora optou pelo "apertar os cintos", ora pela lógica do "lutar para negociar, negociar para mudar". Este tipo de postura explica o porquê de tantas tensões entre a direção partidária e a base sindical responsável pela aplicação das propostas gerais do partido, bem como, em muitos casos, com a dinâmica imposta pela classe. ${ }^{5} \mathrm{O}$ partido pareceu viver sempre um lugar contraditório, tendo em vista o descompasso entre suas formulações gerais e a dinâmica social concreta.

O partido buscou, em termos de sua inserção no sistema político, a demonstração constante de que era confiável e poderia atuar no interior deste sem buscar sua desarticulação. Dada a sua condição de ilegalidade, a incipiência do sistema democrático na vida política nacional e sua lógica de ação política, a conquista e a manutenção da democracia e, a partir daí, a obtenção de mudanças estruturais na sociedade, foram a tônica da ação do partido ao longo do período. ${ }^{6} \mathrm{O}$ momento, curto, no qual esposou posturas esquerdizantes, em fins dos anos 1940 e início dos 1950, era sempre negado posteriormente e servia de exemplo do que não se devia repetir. Essa justificativa explicará a muitas vezes assumida, ainda que de forma constrangida, posição de partido da ordem. Será mesmo com este tipo de proposta

5. Daí, em alguns momentos, ter se falado na existência dos dois $P c s$, ainda que se perceba que o processo se dava de forma muito mais complexa. Ver: Santana (2012) e Costa (1995).

6. Para uma análise de fundo da recorrência da proposta democrática nas linhas políticas do $\mathrm{PCB}$ e de que maneira seu conteúdo sofreu alterações ao longo das conjunturas na história do partido, ver: Vianna (1988).

Aarào Reis (1986) assinala que as relações do PCB com a democracia se davam de forma instrumental. Isto ficaria claramente explicitado no período imediatamente prégolpe.

176 que o partido, oficialmente, combaterá sempre que achar necessário, interna e externamente, as posturas que possam desestabilizar os referidos processos vinculados à democratização. $\mathrm{O}$ combate da agremiação se estabelece à direita, mas também à esquerda no que o partido chamava de desvios esquerdistas.

$\mathrm{O}$ PCB tentou sempre funcionar como um ponto de equilíbrio para a instável democracia brasileira. Assim, recolheu as críticas dos setores mais à esquerda e não conseguiu se colocar como confiável para as elites nacionais que, sempre que puderam e quiseram, transformaram o partido no responsável, real ou fictício, por todos os problemas de instabilidade política que por ventura o país atravessasse.

Será assim que, na Constituinte de 1946, se para a esquerda o partido não defendia de forma suficiente uma trajetória independente e autônomo para a classe trabalhadora com sua postura ambígua diante das greves, para a direita, era exatamente o partido que estava por trás de todas as mobilizações; em 1964, se para a esquerda o partido defendia propostas reformistas e seguia de reboque ao populismo, para a direita, os comunistas estavam por trás da república sindicalista; ao longo dos anos de chumbo, se para a esquerda o partido continuava equivocado ao defender, em termos de frente democrática, a via pacífica de enfrentamento contra a ditadura, para os generais o perigo era o mesmo e o partido, ainda que sem pegar em armas, sofreu tão duramente quanto os grupos guerrilheiros; e já no período de inflexão dos governos militares, em fins dos anos setenta, quando a esquerda criticava o partido por sua postura reformista e negocista frente ao regime, os conservadores, quando da reforma partidária, que inclusive possibilitou a 
existência legal de setores mais à esquerda, não proporcionaram aos comunistas a legalidade que só virá, tardiamente, em 1985.

$\mathrm{Na}$ maior parte do período, ao mesmo tempo em que busca seguir uma orientação política moderada, cheia de cautela, o PCB tenta lidar com uma realidade bastante dinâmica e que o empurrava para posturas nem sempre consentâneas com suas formulações. ${ }^{7}$ Esta será a marca e a contradição da inserção do partido no período. Se buscava ser confiável e aceitável ao sistema político, tentando evitar greves, mobilizações, etc., o partido teve que aceitar e incorporar as práticas vindas de sua militância e da própria classe trabalhadora que pareciam pouco afeitas à lógicas de ação afastadas de sua realidade. É assim, que ainda que com retardo, a agremiação tem de passar a ser mais flexível com relação às greves em 1946; trabalhar no sentido das reformas de base " $n a$ lei ou na marra", no início dos anos sessenta; e se integrar aos setores sindicais combativos no início dos anos noventa. Analisando as contradições na prática do partido no início dos anos '60,

Era como se o partido tivesse uma linha oficial conciliadora, mas, diante do movimento social em radicalização, tivesse de assumir, pelo menos em parte, esta radicalização, senão perderia bases e influência política. Mas isso acabava tendo implicações na linha política. ${ }^{8}$

Um dos elementos que, muitas das vezes, acirrava as contradições entre orientação e

7. Na fase esquerdizante, o partido padeceu do problema de forma invertida. Tentou fabricar, sem sucesso, um processo revolucionário da noite para o dia e empurrar o movimento dos trabalhadores nesta direção.

8. Como bem indica Aàrao Reis (1986, p. 54). prática política do partido era a luta pela hegemonia e posição proeminente no movimento dos trabalhadores. Ela impelia os comunistas a travar uma série de combates com as outras forças existentes e militantes no meio operário e sindical. Ao longo do período podemos indicar que os grandes embates se travaram com os "pelegos" e o Partido Trabalhista Brasileiro (de agora em diante, PTB) no pré-64, e contra o Partido dos Trabalhadores (de agora em diante, PT) e a Central Única dos Trabalhadores (se agora em diante CUT) nos anos oitenta.

No caso do pré-64, o PCB desenvolveu uma luta intensa para apear os setores "pelegos" dos postos no interior da estrutura sindical. A luta era para vencê-los ou, ao menos, menos hegemonizá-los. Mesmo defendendo a política de "unidade" no meio sindical, onde havia espaços mesmo para os "pelegos", os comunistas não se furtaram de definir uma clara linha até onde podiam ir suportando os setores conservadores. Após aquele limite, não evitaram trilhar caminho próprio $\mathrm{e}$ independente daqueles. ${ }^{9}$

No que diz respeito aos setores trabalhistas, o $\mathrm{PCB}$ vai em um crescendo, a partir de meados dos anos 1950, construir uma aliança que caminhando em contraposição aos setores conservadores, conquistará a hegemonia da parcela mais importante e organizada do sindicalismo nacional na entrada da década seguinte. Ainda que aliados, os dois setores não se furtaram de buscar hegemonizar um ao outro. Competindo em aliança, ${ }^{10}$ os comunistas

9. Assim foi quando da criação da Confederação Geral dos Trabalhadores do Brasil (CGTB) em 1946 e na criação do Comando Geral dos Trabalhadores (CGT) em 1962.

10. Processo identificado por Spindel (1980). 
tentarão ir galgando mais espaços no interior do movimento sindical. Assim, a partir de um intenso trabalho junto às bases, $\mathrm{O} P C B$ conseguirá, ainda que politicamente aliado com os setores progressistas do PTB, alcançar os principais postos no interior da estrutura sindical corporativa no momento anterior ao golpe militar. ${ }^{11}$

O quadro se complexificará com a nova dinâmica social encaminhada pelo golpe militar. As avaliações acerca das ações do partido antes e depois do golpe, bem como as formas de enfrentamento ao regime, faz surgir uma plêiade de diferentes grupos no interior $\mathrm{da}$ esquerda. O próprio desenvolvimento capitalista sob a ditadura produziria uma intensificação de cenários já vislumbrados em fins dos anos cinquenta. O incremento da instalação de plantas modernas deu origem também o incremento de um setor moderno na indústria, o qual trazia consigo uma série de novas perspectivas. Será a junção destes novos fatores e novos atores que produzirá um quadro que, mesmo rapidamente identificado pelo partido, foi por ele ignorado.

Desde o golpe militar e ao longo de toda a duração da ditadura, o PCB defenderá uma atuação baseada em amplas forças sociais

11. Delgado (1990) traz um quadro de influência dos dois partidos nos organismos intersindicais, oficiais ou paralelos. A autora, cotejando seus dados sobre o PTB com aqueles apontados em Chilcote (1982) para o PCB, indica que em nenhum daqueles órgãos os trabalhistas conseguiam superar, no máximo igualando, a influência comunista. Claro está que este tipo de influência pode e deve ser relativizada tendo em vista que os dois setores praticamente consolidaram um bloco único, sedimentado pelo nacionalismo. Telles (1962) e Santana (2012) indicam que, em alguns casos, apesar do controle sobre os órgãos sindicais, os comunistas, defensores da política de unidade, sem querer rompê-la, ainda seguiam a reboque dos trabalhistas.

178 que, primeiro, garanta o enfraquecimento do regime; depois, que sustente a transição e, posteriormente, subsidie o regime democrático. Esta linha política, levada aos sindicatos, fez com que os comunistas intensificassem $\mathrm{e}$ estreitassem suas alianças com os setores mais conservadores do movimento sindical e se afastassem do polo dinâmico que surgiria em fins dos anos setenta. Tal perspectiva levará o partido a um enfraquecimento progressivo e a um ponto de quase nenhuma influência no meio sindical pouco antes de sua extinção oficial em 1992.

O PCB que no pré-1964 travaram uma intensa luta contra os setores "pelegos"; no pós-golpe, acabava por atrelar seu destino aos desígnios daquele setor. Baseando-se em sua linha política mais geral que recusava posturas de enfrentamento e tendo seu campo político ocupado à esquerda, o PCB caminhará progressivamente para a perda de seu sentido histórico naquela conjuntura.

\section{O Partido, o Estado e a estrutura sindical}

Entre os aspectos que marcam a diferenciação entre os períodos em tela, a relação do $\mathrm{PCB}$ com o Estado ocupa um lugar importante. Antes do golpe de 1964, de forma mais marcada no momento imediatamente anterior ao golpe, o PCB, mesmo que agindo na ilegalidade, transitavam bem junto aos setores no poder. Tendo em vista sua aliança com os setores progressistas do PTB e sua aproximação ao presidente João Goulart; e, desfrutando de prestígio e força no meio sindical, o PCB terá uma margem de manobra bastante ampliada. ${ }^{12}$

12. Daí a afirmação atribuída à Prestes de que os 
E é contando com o auxílio do Estado que os progressistas conseguem dar preciosos passos na destituição dos "pelegos" dos órgãos centrais de representação sindical dos trabalhadores. ${ }^{13}$

As condições nas quais operavam os comunistas seriam profundamente alteradas no pós-golpe. Os novos governantes colocaram os sindicatos em um lugar que não necessitava mais dos comunistas, na medida em que a perspectiva mobilizatória foi trocada pela lógica do assistencialismo e da inação. $\mathrm{O}$ PCB se tornaria mais uma vez, de fato e de direito, um partido proscrito, com o qual não interessava ao regime manter relações que não fossem as de perseguição.

Os comunistas, como já haviam vivido em sua história, terão seus acessos, formais ou informais, a vida política nacional, obstruídos. Porém, a opção agora, diferentemente de 1947, quando o partido saltou rapidamente do reformismo para o esquerdismo, seria a de tentar penetrar novamente na estrutura sindical e ampliar os espaços partidários de ação.

No campo prático da política, os comunistas acreditavam que deveriam optar entre os grupos esquerdistas, que criticavam duramente

comunistas estavam no governo, mas não eram governo. Ver Vinhas (1982, p. 193).

13. Processo que incluiu também movimentos de idas e vindas por parte do governo de Jango. Quando precisava das mobilizações o governo incentivava o avanço dos progressistas; quando buscava escapar ao controle destes, o governo incentivava os setores conservadores no interior do movimento. Vale dizer, aqui, que não compartilhamos da visão de que este processo se dava de forma unilateral e manipulatória, como se um lado pudesse, pura e simplesmente, à revelia dos projetos do outro polo, coordenar e comandar as suas ações. A proposta analítica de Castro Gomes (1988), utilizada em sua análise de períodos anteriores, nos parece mais adequada para dar conta da complexidade envolvida nestes processos. a estrutura sindical, e os "pelegos" já nela acomodados pelo regime militar. Assim, tendo em vista sua orientação geral, os comunistas vão se aproximar dos setores mais conservadores do movimento sindical e que ocupavam os postos chave da estrutura após a cassação dos progressistas. ${ }^{14}$

Nessa dimensão da relação com o Estado, a estrutura sindical vai ocupar proeminência. Se não foram rápidos o suficiente, no pré-golpe, no que diz respeito das mudanças na legislação, eles consolidaram uma alteração sensível na lógica de atuação do sindicalismo oficial. Orientados por uma política progressista, em geral, e de democratização da vida sindical em particular, os comunistas impuseram um forte combate aos setores conservadores e "pelegos" atuantes no movimento. As direções sindicais que tiveram a aliança comunista-trabalhista à frente, com todos os limites, garantiram a incorporação e participação dos trabalhadores na vida sindical, servindo de pólo aglutinador da democratização sindical.

Como o partido queria aumentar seu poder entre os trabalhadores e os sindicatos, transformando os sindicatos em peças importantes de pressão no jogo político, essa postura ganhava importância. A prática do partido ao longo do período anterior ao golpe

14. Ainda que não de forma exclusiva, podemos dizer que as relações entre os comunistas e os governos no período pré-golpe militar, parecia confirmar a estratégia da organização de que apesar de fora, mas com força no movimento sindical, poderia interferir. Contudo, havia alguma fragilidade nesta interferência. Percebe-se que com toda a sua força e vinculação aos movimentos sociais, os comunistas só puderam transitar e atuar à medida que eram funcionais aos governos, em termos de seus vínculos com a classe trabalhadora. Encerrada esta necessidade, no regime militar, os comunistas enfrentaram enormes dificuldades para recompor seu potencial de ação. 
militar de 1964 esteve longe de ser distanciada da base sindical. ${ }^{15}$ Os comunistas buscaram incessantemente organizar os trabalhadores dentro das empresas. Este trabalho serviu de pilar de sustentação aos avanços comunistas na ocupação de espaços dentro da estrutura sindical oficial.

Se a estrutura permaneceu intacta, nem por isso devemos deixar de perceber, a duplicação de mão produzida com a entrada dos setores progressistas para o seu interior. ${ }^{16} \mathrm{O}$ que se impôs foi uma nova perspectiva que redirecionasse o sindicato para a representação dos interesses dos trabalhadores. As comissões sindicais de empresa, criadas e ou estimuladas pelos comunistas entre os metalúrgicos do RJ (Santana, 2012), só para citar um exemplo, estão muito longe de ser um instrumento de atrelamento dos trabalhadores ao engodo do populismo. Não se deve perder de vista o fato de que tais comissões serviram aos trabalhadores para monitorar a atividade de seus representantes e colocar-lhes sobre pressão quando não correspondiam às expectativas. O mesmo pode se dizer com a criação das Intersindicais que pulularam ao longo do período. Parece simplório olhá-las apenas nos termos de um mero instrumento para dar sangue e agilidade a uma combalida estrutura oficial. Ao mesmo tempo, em que controlavam os órgãos representativos dos trabalhadores, os comunistas buscavam com isto pleitear mais espaços políticos gerais, utilizando-os muitas

15. É interessante notar que apesar de se encontrarem em lados opostos no espectro analítico sobre a conjuntura, tanto Weffort (1973 e 1978), quanto Vianna (1983), apesar de justificativas diferenciadas, aceitam a tese do fraco envolvimento dos comunistas com o trabalho de base. Conforme se verá, pesquisas mais recentes relativizam esta tese.

16. Conforme bem indicado por Vianna (1983). vezes de elemento de pressão contra o que avaliavam ser políticas contrárias aos interesses dos trabalhadores.

Ainda que não estivesse nos horizontes de preocupação dos comunistas uma destruição imediata e rápida da estrutura sindical, eles foram buscando fazer apropriações por dentro dela. Neste sentido pesavam tanto uma estratégia geral, já mencionada; mas tambémfato sempre recorrente e mencionado com insistência-, à autocrítica dos efeitos nocivos ao partido trazidos pelo abandono dos sindicatos oficiais e a tentativa de estabelecer uma estrutura paralela ao longo do período 1948/1952. ${ }^{17}$ Assim, cautelosa e timidamente, os comunistas foram tentando se livrar do que consideravam um obstáculo em termos do acesso e mobilização dos trabalhadores.

Os comunistas acreditavam que por dentro da estrutura poderiam alterá-la de acordo com seu interesse. Sabiam de seus limites, mas acreditavam que poderiam aumentar os espaços de ação em seu interior. Os comunistas talvez tenham percebido, por tê-la enfrentado anos antes sem sucesso, a força não só da estrutura sindical corporativa, mas da cultura que se produzira em torno dela e que não se dobraria de uma hora para outra. ${ }^{18}$

17. Esta demarcação do chamado período esquerdizante se refere à atuação oficial comunista no movimento sindical.

18. Por outro lado, percebiam também que, como indicou Aarào Reis (1997), para as lideranças sindicais de fins dos anos setenta, mas que serve bem para a experiência passada: "Se a estrutura sindical populista fosse tão maldita assim, como poderia gerar no seu ventre gente tão valorosa?". 


\section{O PCB na ditadura}

Se a prática comunista junto aos sindicatos no pré-1964 foi norteada por alguns dos pontos aqui já mencionados; no pós-golpe, algumas mudanças sutis vão ocorrer, mas no geral, a lógica permanece. $\mathrm{O}$ PCB continuou, em termos sindicais a defender a entrada e reocupação dos postos onde eles haviam sido perdidos. Não se colocava mais a questão de construir estruturas paralelas, ${ }^{19}$ mas sim de voltar aos sindicatos e fazê-los novamente atuar em benefício da luta dos trabalhadores. O fato é que se no período anterior, acobertados por um governo um tanto quanto complacente, os comunistas trabalharam no sentido de disputar com os setores conservadores os espaços dentro da estrutura, agora teriam que, sob uma ditadura, serem bem mais cautelosos.

Cassados e perseguidos, os comunistas tinham dificuldades mesmo de organizar-se de novo no meio sindical. Além disso, o governo ia dificultando o quanto podia a aparição e a vitória de chapas pouco afeitas às suas novas propostas para os sindicatos. Junte-se a isso outros dois fatores. $\mathrm{O} \mathrm{PCB}$ vê surgir por todos os lados dissensões na esquerda, oriundas ou não dele, que caminharão rapidamente por uma opção revolucionária. Por seu lado, o partido definia-se mais uma vez por uma postura de enfrentamento pacífico ao regime. Os comunistas, que sempre estiveram à esquerda no meio sindical e político, no polo oposto dos "pelegos" e tendo ao centro o PTB, viam-se agora lançados para o centro entre os "pelegos" e o que consideravam esquerdismo. Ainda que com certa resistência de suas bases, o partido migra rapidamente para uma aproximação

19. Como aquelas tentadas pelo partido, por fora do sindicato oficial, entre 1948/1952. e aliança com os setores conservadores no sindicalismo.

Esta aliança não diminuiu a importância e a influência do $\mathrm{PCB}$ nos parcos espaços de atuação no meio sindical ao longo dos anos 1970. Porém, a virada da década servirá para ir indicando que o partido fazia uma escolha equivocada de alianças, o que the garantiria uma crise definitiva.

Quando do reaparecimento do sindicalismo a céu aberto em fins dos anos setenta, o PCB ainda mantinha certa importância no seio do movimento e, de alguma maneira, mesmo associado aos "pelegos", ia defendendo posições em termos de trazer os sindicatos à luta, diferentemente de seus aliados. $\mathrm{O}$ fato é que novos atores entram em cena e propondo práticas combativas, marcadas pelo enfrentamento, ameaçam a soberania do Partidão enquanto senhor supremo da representação da esquerda e dos trabalhadores. O partido vai buscar garantir os seus espaços informado por uma linha política geral que os afastava dos combativos e os aproximava, quase que os anexando, aos conservadores.

Aqui, mais uma vez, o dado pragmático entrou como elemento-chave nas opções e leitura dos princípios. Ainda que alguns setores envolvidos insistam na versão de que uma distinção de política sindical efetivara a cisão, podemos perceber que foi mais a orientação política geral dos grupos- comunistas e combativos- que os fez se separarem formalmente com a criação da CUT em 1983, quando haviam caminhado juntos, inclusive com os "pelegos", até ali. Apesar de trabalharem na perspectiva da unidade, os comunistas visavam claramente a manutenção de sua hegemonia no movimento sindical e, para isso,já contavam não só com sindicatos sob 
seu controle, mas também com a aproximação aos "pelegos". Já os combativos incluíam tanto sindicalistas que já estavam ocupando postos no interior da estrutura oficial, mas também setores que de fora dela buscavam nela entrar para propor sua alteração, como as Oposições Sindicais. ${ }^{20}$ Tentando manter a disputa na órbita da estrutura oficial, o PCB, assim como os "pelegos", não viu com bons olhos o avanço dos combativos, bem como sua perspectiva de, para além dos sindicatos oficiais, abrir espaços para as Oposições independentemente dos sindicatos "pelegos", que supostamente representavam as categorias onde atuavam as Oposiçôes. Isto foi visto como paralelismo. Este fato deflagrou todo um processo que dividiu formalmente o movimento sindical brasileiro no início dos anos oitenta. Na verdade, o que estava em jogo era a hegemonia no interior do movimento e a busca de canais que possibilitassem enfraquecer os oponentes.

Os comunistas que sempre estiveram alinhados em favor de posições progressistas para a vida sindical e associados àqueles que também compartilhavam, ainda que minimamente, desta ideia, agora, solidificados no bloco dos conservadores, acabavam por ir contra as forças que buscavam a democratização e o arejamento sindical.

Mesmo que levasse em conta o quadro em que estava inserido, o PCB subestimou as possibilidades de sobrevida tanto do PT quanto da CUT, tendo em vista não só o contexto de regime militar, como o que chamava de estreiteza política daqueles atores. Influenciado

20. O movimento das Oposições Sindicais agrupava uma série de posições diferenciadas que ia desde as que defendiam a participação nos marcos da estrutura corporativa para alterá-la até aquelas que recusavam mesmo este tipo de atuação. por uma linha de transição democrática segura, o partido via os setores combativos enquanto uma verdadeira ameaça para o processo da transição. Ao ter dificuldade de entendimento das posições políticas que lhe eram diferentes, o partido parecia não perceber que em termos sindicais, muitas das posições poderiam se afinar sem grandes choques.

Apesar de várias tentativas internas de mudança de linha e aproximar o partido dos setores combativos, estas posições foram derrotadas sucessivamente e o PCB prosseguiu caminhando de cabeça erguida, sem olhar o beco sem saída em que se metia. Uma após a outra foram caindo as cidadelas importantes que davam aos comunistas certo prestígio e força dentro do movimento.

Polarizado, o movimento sindical parecia só ter lugar entre os "pelegos" ou entre os combativos. Os dois setores cresciam, ainda que mudando e redefinindo formas, e o PCB reduzia seu potencial. Sem este prestígio e força dentro do movimento sindical, completamente desenraizado das empresas, sofrendo a concorrência eficiente do PT e da CUT - que se credenciavam definitivamente como os novos organismos pelos quais parcela significativa da classe trabalhadora vocalizaria suas demandas - e sem conseguir despontar mesmo como um polo político de peso, o que restaria a este partido já de setenta anos - que em muitas vezes ao longo de sua tortuosa história encarou o fim de frente e lidou com ele -, em um momento no qual ele parecia não ter mais lugar no espaço, senão repensar completamente sua própria existência?

$\mathrm{Na}$ virada dos anos setenta e início dos anos oitenta, o partido ainda que trabalhando no sentido da democracia, no social, conjugou 
esforços com setores pouco ou nada afeitos à democracia e reformas no meio sindical. $\mathrm{Se}$, antes, a maior parte do tempo o partido conseguia se identificar com os polos dinâmicos na política sindical; agora, optava pelo atraso e se distanciava do movimento vivo, ainda que alegasse o oposto.

Este aspecto da democratização e reforma em termos sindicais foi um delimitador na ascensão e na queda dos comunistas. Enquanto no passado haviam utilizado esta postura para ultrapassar os "pelegos", no presente acabavam por ser ultrapassados por setores que visavam nada mais que esta democratização da vida sindical e uma transformação na estrutura sindical. ${ }^{21}$

A estrutura sindical corporativa ia, assim, mostrando mais uma vez sua força. A própria mudança de hegemonia entre os setores da esquerda no movimento sindical se dava não a partir da disputa entre uma força de dentro dela e outra que buscasse uma alternativa a ela. A ultrapassagem foi feita por dentro da estrutura. $\mathrm{O}$ determinante no enfrentamento não era criar o paralelo, mas sim, no limite, associar o oficial e o paralelo. Os comunistas fizeram isto à perfeição no passado. A partir de dentro da estrutura, com articulações paralelas a ela, conseguiram se sobrepor aos "pelegos" e competir com os trabalhistas com mais vantagens do que haviam conseguido pelo caminho estritamente paralelo. Nos anos oitenta, por não estarem mais identificados com o polo dinâmico das forças atuantes no movimento sindical, os comunistas não podiam significar nenhuma mudança que impusesse à estrutura uma nova dinâmica e a

21. Sobre os limites dos projetos destes setores, apesar de sua virulenta retórica no que diz respeito às mudanças na estrutura, ver Boito Jr. (1991). fizesse funcionar, ainda que limitadamente, em favor das reivindicações dos trabalhadores. É por isso que eles perdem sua significação no movimento sindical. A perda de significação no interior do movimento sindical não foi a única. $\mathrm{Na}$ arena política geral, os comunistas tinham sua inserção também restrita. Se sempre haviam retirado sua força política de seu poderio no interior do sindicalismo, quando esse diminuiu, aquele se enfraqueceu junto.

\section{Conclusão}

A trajetória do $\mathrm{PCB}$ e sua relação com a classe trabalhadora brasileira ao longo dos dois períodos analisados abrem caminhos interessantes para pensarmos as relações de partidos de esquerda com os movimentos dos trabalhadores. A partir da junção de efeitos estruturais e conjunturais como, entre outros, os distintos momentos de formação capitalista e da classe trabalhadora, as ações do Estado, fatores internos e externos ao partido, suas orientações e ações no meio político e sindical, bem como a dimensão concorrencial entre os setores de esquerda em termos da representação dos trabalhadores, podemos compreender os limites e as possibilidades experimentados pelo PCB nos dois períodos, entendendo os aspectos e seus referidos pesos no apogeu e na crise do partido.

Quando observamos os dos períodos percebemos que as formulações sindicais, centros de nossa preocupação, na proposta do $\mathrm{PCB}$ pouco se alteraram. Em seus documentos, nos dois momentos, mantinha-se a importância de temas, tais como, da luta por liberdade e autonomia sindical; da organização nos locais 
de trabalho como centro fundamental na organização dos trabalhadores e da construção de uma central sindical nacional que levasse a cabo o processo unitário de organização dos trabalhadores brasileiros. Para além disso, como já indicamos, os comunistas se posicionarão a favor da manutenção da unicidade sindical e duramente contrários ao pluralismo sindical. A luta pela unicidade, que é o monopólio da representação de um sindicato sobre uma base determinada de trabalhadores, era defendida enquanto uma questão de princípio pelo partido. Defensor ardoroso da unidade, não poderia optar por um mecanismo que supostamente pulverizasse os trabalhadores de uma mesma base em vários sindicatos.

Este argumento foi muito utilizado politicamente pelo partido em fins dos anos setenta e ao longo dos oitenta, servindo de base para acusar os oponentes que buscavam seu espaço, a crítica de divisionistas e fecharlhes qualquer possibilidade de avanço sobre a estrutura sindical, a não ser aquelas que passavam pela disputa por dentro do sindicato já instituído.

No que diz respeito à relação entre a linha política geral do partido e sua atuação junto ao sindicalismo foi no primeiro momento de complementação e no segundo momento de contradição. Se no momento imediatamente anterior ao golpe, a luta pela democratização e avanço das reformas fez com que o partido se empenhasse na democratização e avanço também de posturas progressistas no meio sindical, nos anos oitenta o partido que lutava pela democratização via em alguns dos setores atuantes no espectro da esquerda, um perigo à estabilização democrática e acaba por se atirar contra eles, buscando impedi-los de avançar sobre as posições já conquistadas pelo partido. ${ }^{22}$ Assim, o princípio da unicidade, que já fora utilizado contra os "pelegos" no pré-golpe, pôde ser usado também para tentar barrar os avanços progressistas na transição democrática.

Ao lutar por reformas e democracia tanto no âmbito da sociedade como no dos sindicatos, incorporando os trabalhadores no processo, ao longo dos anos 1950 e início dos anos 1960, o PCB obteve sucesso na sua penetração no meio sindical e operário. Nos anos 1980, ao se manter na luta pela democracia - que agora, pelas próprias condições, já não detinha o caráter socializante vinculado às reformas estruturais do início dos anos sessenta -, sem, contudo, incorporar este valor na perspectiva sindical, tendo em vista que o confundia com o possível avanço de seus oponentes desestabilizadores, o partido se isolou completamente do movimento, se afastando do que, por essência, seria sua base de existência.

Quando observamos os aspectos relativos à hegemonia nos setores político e sindical de esquerda, o PCB reinou pelo menos de 1945 a 1978 como a referência da esquerda. E, seja por tradição, tamanho, militância e durabilidade, este partido prosseguiu como o representante da classe trabalhadora até fins dos anos setenta quando setores sociais emergentes se agrupam em torno da proposta do PT e vão abrir uma alternativa até então nunca enfrentada pelo PCB.

Ao mesmo tempo, em que buscava trabalhar o campo institucional- assim como o PCB e

22. De alguma maneira, mesmo que em formato diferente, o partido repetia aquelas proposições de seu secretário geral Luís Carlos Prestes, no período de redemocratização nos anos 1940, de que mobilizações mais radicalizadas serviriam ao fascismo. 
o PTB no passado-, o PT trazia uma forte proposta de enraizamento e sustentação de suas propostas pela base, no que a CUT jogava papel central- fato sempre utilizado pelos comunistas e de forma não comparável pelo PTB. ${ }^{23}$ Assim, surgia um partido com condições de superar o PCB em termos de sua posição, política e sindical, de representante da classe trabalhadora no Brasil.

$$
\propto \ddot{e} \propto
$$

$\overline{\text { 23. Ver Delgado, } 1990}$ e Reis F. ${ }^{\circ}, 1986$. 


\section{Referências Bibliográficas}

Aarào Reis, D. A. (1986). Questões históricas (exposição). En M. A. Garcia (org.), As esquerdas e a democracia (pp, 45-60). Rio de Janeiro: Paz e Terra/Cedec.

Aarào Reis, D. A. (1997). A maldição do populismo. Boletim Linha Direta, (330), 5-15, 1997.

Boito Jr., A. (1991). O sindicalismo de estado no Brasil. São Paulo: Hucitec/Unicamp.

Carone, E. (1982a). O PCB 1922/1943, vol. 1. São Paulo: Difel.

Carone, E. (1982b). O PCB 1943/1964, vol. 2, São Paulo: Difel.

Carone, E. (1982c dgard, O PCB 1964/1982, vol. 3. São Paulo: Difel.

Chilcote, R. (1982). Partido Comunista Brasileiro - conflito e integração. Rio de Janeiro: Graal.

Costa, H. (1995). Em busca da memória - comissão de fábrica, partido e sindicato no pós-guerra. São Paulo: Scritta.

De Castro Gomes, A. (1988). A invenção do trabalbismo. São Paulo: Vértice/IUPERJ.

Delgado, L. (1986). O comando geral dos trabalhadores no Brasil 1961/1964. Petrópolis: Vozes.

Delgado, L. (1990). Neves, Partido-sindicato-estado: integração e ruptura na crise do populismo. Ponencia presentada en XIV Reunião Anual da ANPOCS, Caxambu, Brasil.

Erickson, K. P. (1979). Sindicalismo no processo politico no Brasil. São Paulo: Brasiliense.

French, J. (1995). O ABC dos operários. Conflitos e alianças de classe em São Paulo - 1900-1950. São Paulo: Hucitec/Pref. Mun. de São Caetano do Sul.

Gadotti, M. y Pereira, O. (1989). Pra que PT. São Paulo: Editora Cortez.

Garcia, M. A. (1986). (org.). As esquerdas e a democracia. São Paulo: Cedec.

Giannotti, V. y Neto, S. (1991). CUT - ontem e hoje. Petrópolis: Vozes.

Giovanetti Netto, E. (1986). O PCB na Assembléia Constituinte de 1946. São Paulo: Novos Rumos.

Gorender, J. (1987). Combate nas trevas. São Paulo: Ática.

Gramsci, A. (1978). Maquiavel, a politica e o estado moderno. Rio de janeiro: Civilização Brasileira.

Keck, M. (1992). The Workers' Party and Democratisation in Brazil. London: Yale University Press.

Martins, H. (1979). O Estado e a burocratização do sindicato no Brasil. São Paulo: Hucitec. 
Martins, H. (1994). Igreja e movimento operário no ABC. São Paulo/S.C. do Sul: Hucitec/Prefeitura de São Caetano do Sul.

Meneguello, R. (1989). PT: a formação de um partido (1979-1982). Rio de Janeiro: Paz e Terra.

Rodrigues, I. J. (1993). Trabalhadores, sindicalismo e democracia: a trajetória da CUT. (Tese Doutoral inédita). Universidad de San Pablo, San Pablo, Brasil.

Rodrigues, L. M. (1981). O PCB: os dirigentes e a organização. En B. Fausto (Coord.), História Geral da Civilização Brasileira vol. 10 (pp. 415-446). São Paulo: Difel.

Sader, E. (1988). Quando novos personagens entraram em cena. Rio de janeiro. Paz e Terra.

Santana, M. A. (2001). Homens Partidos: comunistas e sindicatos no Brasil. São Paulo/ Rio de Janeiro: Boitempo/Unirio.

Santana, M. A. (2012). Bravos companheiros: comunistas e metalúrgicos no Rio de Janeiro (1945-1964). Rio de Janeiro: 7Letras.

Spindel, A. (1980). O partido comunista na gênese do Populismo. São Paulo: Símbolo.

Telles, J. (1962). O movimento sindical no Brasil. Rio de Janeiro: Vitória.

Vianna, L. W. (1983). A classe operária e a abertura. São Paulo: Cerifa.

Vinhas, M. (1982). O partidão - a luta por um partido de massas (1922/1974). São Paulo: Hucitec.

Weffort, F. (1973). Origens do sindicalismo populista no Brasil (A conjuntura do Após-guerra). Estudos Cebrap, 1(4), 63-77.

Weffort, F. (1978). Os sindicatos na política (Brasil 1955-1964). Ensaios de Opinião, 2(5), 10-36. 